\title{
ANALISIS KELAYAKAN FINANSIAL USAHA PENGOLAHAN GULA AREN DI KECAMATAN RANTAU KABUPATEN ACEH TAMIANG
}

\author{
Muslimah $^{1} /$ Alimsyahputra $^{2}$ \\ ${ }^{1}$ Dosen Tetap Program Studi Agribisnis Fakultas Pertanian \\ ${ }^{2}$ Mahasiswa Fakultas Pertanian Program Studi Agribisnis \\ Universitas Samudra, Langsa-Aceh
}

\section{RINGKASAN}

Tujuan penelitian yaitu untuk mengetahui pengaruh harga, produksi dan tenaga kerja terhadap pendapatan usaha pengolahan gula aren di Kecamatan Rantau Kabupaten Aceh Tamiang. Penelitian ini dilakukan di Kecamatan Rantau Kabupaten Aceh Tamiang dengan menggunakan metode survey. Penentuan lokasi penelitian dilakukan dengan sengaja di Kecamatan Rantau Kabupaten Aceh Tamiang dengan pertimbangan bahwa kecamatan tersebut merupakan daerah sentra usaha pengolahan gula aren. Objek penelitian ini adalah usaha pengolahan gula aren aren yang mengolah air nira aren menjadi gula aren. Ruang lingkup penelitian meliputi harga, produksi, penggunaan tenaga kerja dan pendapatan pada usaha pengolahan gula aren. Model analisis data yang digunakan dalam penelitian ini adalah dengan menggunakan regresi linear berganda.

Hasil penelitian: Karakteristik pengusaha sampel adalah umur rata-rata pengusaha gula aren sampel adalah 46,29 tahun, tingkat pendidikan rata-rata adalah 9,10 tahun, pengalaman berusaha gula aren 10,10 tahun dan jumlah tanggungan keluarga pengusaha gula aren rata-rata 4 orang. Rata-rata luas lahan usaha pengolahan gula aren sampel adalah sebesar $28,71 \mathrm{~m}^{2}$, rata-rata pengunaan tenaga kerja usaha pengolahan gula aren di Kecamatan Rantau yaitu sebesar 56,41 HKP/Tahun, rata-rata biaya produksi usaha pengolahan gula aren di Kecamatan Rantau yaitu sebesar Rp. 8.507.053,76/tahun, rata-rata produksi usaha pengolahan gula aren di Kecamatan Rantau yaitu sebesar $1.849,06 \mathrm{Kg} /$ tahun, rata-rata pendapatan kotor usaha pengolahan gula aren di Kecamatan Rantau yaitu sebesar Rp.35.067.419,35/tahun dan rata-rata pendapatan bersih usaha pengolahan gula aren di Kecamatan Rantau yaitu sebesar Rp.26.560.365,59/tahun.

Hasil perhitungan analisis linier berganda diperoleh persamaan regresi sebagai berikut: $\mathrm{Y}=$ $97,841+1,741 X_{1}+15,797 X_{2}-0,00041 X_{3}$. Nilai $R^{2}$ sebesar 0,9798 artinya bahwa variabel harga $\left(\mathrm{X}_{1}\right)$, produksi $\left(\mathrm{X}_{2}\right)$ dan tenaga kerja $\left(\mathrm{X}_{3}\right)$ mempengaruhi pendapatan $(\mathrm{Y})$ usaha pengolahan gula aren di Kecamatan Rantau sebesar 97,98 \%. Sisanya sebesar 2,02 \% dipengaruhi faktor lain yang tidak dimasukan dalam model penelitian ini. Secara serempak variabel harga $\left(\mathrm{X}_{1}\right)$, produksi $\left(\mathrm{X}_{2}\right)$ dan tenaga kerja $\left(\mathrm{X}_{3}\right)$ berpengaruh sangat nyata terhadap pendapatan $(\mathrm{Y})$ usaha pengolahan gula aren di Kecamatan Rantau. Secara terpisah variabel harga $\left(X_{1}\right)$ dan tenaga Kerja $\left(X_{3}\right)$ tidak berpengaruh nyata sedangkan produksi $\left(\mathrm{X}_{2}\right)$ berpengaruh sangat nyata terhadap pendapatan $(\mathrm{Y})$ usaha pengolahan gula aren di Kecamatan Rantau.

Kata kunci: usaha, gula aren, harga , produksi, tenaga kerja, pendapatan

\section{PENDAHULUAN \\ Latar Belakang}

Kebutuhan masyarakat terhadap gula aren dalam bentuk padat dengan bentuk cair sama tingginya, karena memiliki kegunaan yang sama yaitu untuk proses pembuatan makanan dan minuman. Pengusaha gula aren memproduksi dalam bentuk cair dan padat, sedangkan masyarakat lebih banyak memilih gula aren dalam bentuk padat karena lebih mudah penyimpanannya dan tahan lebih lama dibandingkan dengan gula aren dalam bentuk cair (Soeseno, 2000:32).

Diantara jenis-jenis industri tanaman pertanian yang ada di Indonesia salah satunya adalah aren (Arenga pinnata, Merr) yaitu palma yang terpenting setelah kelapa (nyiur) karena merupakan tanaman serba guna. Tumbuhan ini dikenal dengan berbagai nama seperti nau, hanau, peluluk, biluluk, kabung, juk atau ijuk (aneka nama lokal di Sumatra dan Semenanjung Malaya); kawung, taren, akol, akel, akere, inru, indu (bahasa-bahasa di Sulawesi); moka, moke, tuwa, tuwak (di Nusa Tenggara), dan lain-lain. Bangsa Belanda mengenalnya sebagai arenpalm atau zuikerpalm dan bangsa Jerman menyebutnya zuckerpalme. Dalam bahasa Inggris disebut sugar palm atau Gomutipalm (Slamet Soeseno, 2000:48).

$$
\text { Gula aren merupakan produk }
$$
agroindustri yang diproduksi oleh industri 
rumah tangga yang umumnya berada di pedesaan. Proses pembuatan gula aren tersebut biasanya dilakukan secara tradisional dan menggunakan peralatan sederhana, jumlah produk yang dihasilkan terbatas. Untuk peningkatan nilai tambah pembuatan gula aren oleh industri rumah tangga (Soeseno, 2000:32).

Gula aren diperoleh dengan menyadap tandan bunga jantan yang mulai mekar dan menghamburkan serbuk sari yang berwarna kuning. Tandan ini mula-mula dimemarkan dengan memukul-mukulnya selama beberapa hari, hingga keluar cairan dari dalamnya. Tandan kemudian dipotong dan diujungnya digantungkan tahang bambu untuk menampung cairan yang menetes. Cairan manis yang diperoleh dinamai nira, berwarna jernih agak keruh. Nira ini tidak tahan lama, maka wadah bambu yang telah berisi harus segera diambil untuk diolah niranya, biasanya sehari dua kali pengambilan yakni pagi dan sore.

Di Kecamatan Rantau Kabupaten Aceh Tamiang para petani aren memproduksi gula aren dalam bentuk cair dan padat. Permintaan gula aren sebagai bahan makanan pengganti gula pasir dan pemanis buatan ini menyebabkan aren menjadi komoditi andalan bagi para petani aren. Peningkatan permintaan gula aren di masyarakat merupakan peluang utama bagi para petani untuk berupaya meningkatkan pendapatannya. Peningkatan pendapatan dilakukan dengan melakukan penambahan produksi sehingga nilai produksinya juga meningkat.

Studi kelayakan bisnis/usaha biasanya menggunakan analisis kelayakan investasi dimana pada dasarnya sama dengan kegiatan investasi. Kelayakan investasi dapat dikelompokkan kedalam kelayakan finansial dan kelayakan ekonomi. Dalam analisis investasi, tujuan utama yang hendak dicapai adalah membandingkan biaya (cost) dan manfaat (benefit) dengan berbagai usulan investasi (Soetriono, 2006:48).

Setiap petani dalam pengelolaan usahataninya mempunyai tujuan yang berbeda-beda. Tujuan usahatani pertama adalah untuk memenuhi kebutuhan keluarga dan yang kedua bertujuan mencari keuntungan secara komersial. Petani kita umumnya bertujuan untuk mencari keuntungan dalam meningkatkan penghasilan/ pendapatannya bukan semata-mata untuk memenuhi kebutuhan keluarga (Soekartawi, 2002:24).

Analisis finansial adalah analisis dimana suatu proyek dilihat dari sudut yang bersifat individual artinya tidak perlu diperhatikan apakah efek atau dampak dalam perekonomian dalam lingkup yang lebih luas. Dalam analisis finansial, yang diperhatikan adalah hasil total atau produktivitas atau keuntungan yang didapat dari semua sumber yang dipakai dalam proyek untuk masyarakat atau perekonomian secara keseluruhan, tanpa melihat siapa yang menyediakan sumber tersebut dan siapa yang menerima hasil proyek tersebut (Kadariah, 2000:46).

Analisis finansial suatu usaha didasarkan oleh beberapa kriteria yaitu; nilai investasi yang akan datang dihitung sekarang, perbandingan total penerimaan dengan total biaya, nilai manfaat bila dibandingkan dengan tingkat bunga bank berlaku dan tingkat pengembalian investasi.

Adapun kriteria yang sering digunakan dalam analisis Kelayakan Finansial adalah 1) NPV (Net Present Value) dan 2) IRR (Internal Rate of Return) dan 3) B/C ratio (Benefit-cost ratio). NPV menetapkan tingkat penerimaan yang ditargetkan seperti discount factor atau discount rate, kemudian menentukan apakah tingkat itu dicapai dengan melihat apakah nilai nol atau positif ( Soetriono, 2006:42).

Usaha pengolahan gula aren yang ada di Kecamatan Rantau umumnya sudah mengarah pada tujuan untuk mencari keuntungan secara komersial. Akan tetapi pengusaha gula aren tidak pernah menghitung bagaimana kelayakan finansial usaha yang dijalankan. Dengan mengetahui kelayakan finansial usaha, pengusaha gula aren dapat mengambil keputusan apakah harus melanjutkan usaha, memperbesar usaha atau menghentikan usaha tersebut. Sehubungan dengan hal tersebut diatas, maka penulis merasa tertarik dan penting untuk meneliti lebih lanjut tentang analisis kelayakan finansial usaha pengolahan gula aren di Kecamatan Rantau Kabupaten Aceh Tamiang.

\section{Identifikasi Masalah}

"Apakah usaha pengolahan gula aren di Kecamatan Rantau Kabupaten Aceh Tamiang layak untuk dikembangkan dari segi finansial?" 


\section{Tujuan Penelitian}

"Untuk mengetahui kelayakan usaha pengolahan gula aren di Kecamatan Rantau Kabupaten Aceh Tamiang apabila dilihat dari segi kelayakan finansial".

\section{Hipotesis Penelitian}

"Usaha pengolahan gula aren di Kecamatan Rantau Kabupaten Aceh Tamiang layak untuk diusahakan dari sisi analisis finansial"

\section{METODOLOGI PENELITIAN}

\section{Lokasi, Objek, Ruang Lingkup dan Waktu} Penelitian

Penelitian ini menggunakan metode survey. Menurut Sugiono (2012:6), "Metode survey digunakan untuk mendapatkan data dari suatu tempat tertentu yang alamiah (bukan buatan), tetapi peneliti melakukan perlakuan dalam pengumpulan data misalnya dengan mengedarkan kuesioner dan sebagainya (perlakuan tidak seperti eksperimen)". Penentuan lokasi penelitian dilakukan dengan sengaja di Kecamatan Rantau Kabupaten Aceh Tamiang dengan pertimbangan bahwa kecamatan tersebut merupakan daerah sentra usaha pengolahan gula aren. Objek penelitian ini adalah usahatani aren yang mengolah air nira aren menjadi gula aren. Ruang lingkup penelitian meliputi biaya produksi, penerimaan, pendapatan, analisis finansial usaha pengolahan gula aren.

\section{Teknik Penentuan Sampel dan Pengumpulan Data Penentuan Sampel}

Populasi dalam penelitian ini adalah pengusaha gula aren yang berada di Kecamatan Rantau. Kecamatan Rantau terdiri dari 16 Desa dimana terdapat 7 desa yang terdapat usaha pengolahan gula aren. Dari 7 desa tersebut diambil 3 desa untuk dijadikan sampel secara purposive, dengan pertimbangan bahwa 3 desa tersebut yang memilki jumlah pengusaha aren yang terbanyak. Metode pengambilan pengusaha sampel dilakukan dengan menggunakan metode sampel jenuh (Total Sampling). Artinya semua populasi dijadikan sampel penelitian karena jumlah populasi yang kecil. Sedangkan menurut Sudjana, (2003:96) menyatakan "Sebaliknya bila populasi kecil, sampel dirumuskan mendekati jumlah populasi. Untuk lebih jelasnya mengenai jumlah populasi dan pengusaha sampel di daerah pene litian dapat dilihat pada tabel III-1 berikut ini:

Tabel III-1. Jumlah Populasi dan Jumlah Sampel Pengusaha Untuk Masing-masing Desa di Kecamatan Rantau Kabupaten Aceh Tamiang, 2016

\begin{tabular}{|l|l|r|r|}
\hline No & Nama Desa & Populasi (Pengusaha) & Sampel (Pengusaha) \\
& & 10 & 10 \\
\hline 1 & Ingin Jaya & 11 & 11 \\
2 & Jamur Labu & 10 & 10 \\
3 & Durian & 31 & 31 \\
\hline \multicolumn{2}{|c|}{ Jumlah } & & \\
\hline
\end{tabular}

Sumber Data : Data Primer, 2016 (diolah)

Tabel III-1 menunjukan bahwa jumlah populasi pengusaha aren yaitu sebanyak 31 orang yang terdiri dari Desa Ingin Jaya sebanyak 10 orang, Desa Jamur Labu sebanyak 11 orang dan Desa Durian sebanyak 10 orang..

\section{Metode Analisis dan Pengujian Hipotesis}

Data yang diperoleh dari lapangan baik data primer maupun data sekunder diolah dengan mentabulasikan dan kemudian dipindahkan ke dalam bentuk tabelaris sesuai dengan kebutuhan analisis.

\section{Analisis Pendapatan}

1) Pendapatan Kotor

$\mathrm{TR}=(\mathrm{Y}) \times(\mathrm{Py}) \ldots \ldots . .(\mathrm{Ken}$ Suratiyah, $2006: 65$ )

Keterangan:

TR : Total penerimaan (Total

Revenue) (Rp/Tahun) 
$\mathrm{Y}$ : Produksi pengolahan gula

aren $(\mathrm{Kg} / \mathrm{Tahun})$

Py : Harga gula aren (Price)

$(\mathrm{Rp} / \mathrm{Kg})$

2) Pendapatan Bersih

$$
\mathrm{Pd}=\mathrm{TR}-\mathrm{TC} \quad \ldots . .
$$

Soekartawi, 2002:58)

Keterangan :

Pd : Pendapatan usaha gula aren $(\mathrm{Rp} / \mathrm{Tahun})$

TR : Penerimaan Total

(total revenue) ( $\mathrm{Rp} / \mathrm{Tahun})$

TC : Biaya total (total cost $)(\mathrm{Rp} / \mathrm{Tahun})$

\section{Pengujian Hipotesis}

Hipotesis yang telah diajukan, dianalisis dengan menggunakan analisis kelayakan investasi dengan rumus sebagai berikut :

\section{a) Analisis NPV}

$$
\mathbf{N P V}=\sum_{\mathbf{t}=\mathbf{1} \quad(\mathbf{1}-\mathbf{i})^{\mathbf{t}}} \frac{\mathrm{Bt}-\mathrm{Ct}}{}
$$

Keterangan :

$\mathrm{B}_{\mathrm{t}}=$ Penerimaan (benefit) finansial dari usaha pengolahan gula aren dalam waktu 1 tahun

$\mathrm{C}_{\mathrm{t}} \quad=$ Biaya finansial usaha pengolahan gula aren dalam waktu 1 tahun

I = Discount Rate

$\mathrm{NVP}=$ Nilai netto sekarang (Soekartawi, 2002)

Kriteria yang dipakai:

- Bila nilai NPV >0 maka usaha dikatakan layak (untung)

- Bila nilai NPV = 0 maka usaha tersebut mengembalikan persis sebesar Opportunity Cost of Capital

- Bila nilai NPV < 0 maka usaha tersebut dikatakan tidak layak (rugi)

\section{b) Analisis Net B/C}

$\sum \stackrel{\mathrm{Bt}-\mathrm{Ct}}{ }$ untuk $B_{t-} C_{t}>$ 0

$$
C_{t}<0
$$

$$
\begin{aligned}
& t=1(1-i)^{t} \\
& \sum \underline{\mathrm{Bt}-\mathrm{Ct}} \text { untuk } B_{t-}
\end{aligned}
$$

$$
t=1(1+i)^{t}
$$

Keterangan :

$\mathrm{Bt}=$ Penerimaan (benefit) finansial dari usaha pengolahan gula aren dalam waktu 1 (satu) tahun

$\mathrm{Ct}=$ Biaya finansial (cost) usaha pengolahan gula aren dalam waktu 1 (satu) tahun digunakan

$\mathrm{i}=$ Opportunity Cost of Capital yang

$\mathrm{t}=$ Jangka waktu usaha

Kriteria yang dipakai:

- Bila B/C > 1 maka usaha tersebut layak diusahakan

- Bila B/C $<1$ maka usaha tersebut tidak layak diusahakan (Soekartawi, 2002:128)

c). Analisis IRR

$$
\text { IRR }=\frac{\mathrm{i}+\sum \frac{\mathbf{B t}-\mathbf{C t}}{\mathbf{t}=\mathbf{1}(\mathbf{1}-\mathbf{I})^{\mathbf{i}}}}{\mathrm{Ct}} 100 \%
$$

$(\mathrm{IRR}=$ nilai penyusutan 1 tahun + pendapatan bersih satu periode usaha

dibagi total biaya finansial satu periode usaha)

Keterangan :

$\mathrm{i}=$ nilai penyusutan 1 tahun

$\mathrm{Bt}=$ Penerimaan (benefit) finansial dari usaha pengolahan gula aren dalam waktu 1 (satu) tahun

$\mathrm{Ct}=$ Biaya finansial (cost) usaha pengolahan gula aren dalam waktu 1 tahun

Kriteria yang dipakai:

1. Bila IRR > Bunga Bank maka usaha tersebut layak diusahakan

2. Bila IRR < Bunga Bank maka usaha tersebut tidak layak diusahakan (Soekartawi, 2002:132)

\section{d) PBP (Payback Priod)}

Payback Period merupakan jangka waktu /periode yang diperlukan untuk membayar kembali semua biaya-biaya yang telah dikeluarkan dalam investasi suatu proyek, dengan rumus sebagai berikut:

$$
P B P=\frac{I}{A b}
$$

Yakob, H. M, 2003: 154)

dimana :

I = besarnya biaya investasi $\mathrm{Ab}=$ benefit bersih yg diperoleh setiap tahunnya 
Dengan Indikator:

- Periode pengembalian modal < umur ekonomis, maka usaha layak diusahakan

- Periode pengembalian modal > umur ekonomis, maka usaha layak diusahakan

\section{Asumsi Dasar Penelitian}

1. Bunga bank yang digunakan adalah bunga bank umum yaitu $12 \%$

2. Waktu perhitungan biaya, produksi dan pendapatan pada 1 (satu) tahun yaitu tahun 2016

3. Waktu perhitungan proyek selama 5 (lima) tahun operasional produksi usaha pengolahan gula aren

4. Upah tenaga kerja disetarakan $\mathrm{Rp}$ 50.000 per HKP

\section{HASIL PENELITIAN DAN PEMBAHASAN}

\section{Karakteristik Pengusaha Gula Aren}

Karakteristik pengusaha gula aren dalam penelitian ini meliputi umur, pendidikan, pengalaman dalam berusaha pengolahan gula aren dan besar tanggungan keluarga. Rini (2005:26), "pengertian karakteristik individu adalah bagian dari pribadi dan melekat pada diri seseorang. Karakteristik ini mendasari tingkah laku seseorang dalam situasi kerja maupun situasi yang lainnya". Karakteristik akan mempengaruhi pengusaha gula aren dalam mengelola usaha selama proses produksi berlangsung. Pengusaha gula aren dalam menjalankan usahanya memiliki fungsi ganda yaitu disamping sebagai manager usaha juga sebagai tenaga kerja usaha.

Umur rata-rata pengusaha gula aren sampel adalah 46,29 tahun, umur tersebut adalah umur yang produktif dalam mengusahakan usaha pengolahan gula aren. Tingkat pendidikan rata-rata adalah 9,10 tahun (SMP), pendidikan pengusaha gula aren sampel masih rendah. Semakin tinggi tingkat pendidikan pengusaha gula aren, maka semakin kreatif pengusaha gula aren dalam mengambil berbagai tindakan usaha, begitu juga sebaliknya semakin rendah tingkat pendidikan Pengusaha gula aren maka semakin lambat dalam mengambil berbagai keputusan usaha. Rata-rata pengalaman berusaha gula aren 10,10 tahun, pengalaman dalam berusaha pengolahan gula aren cukup lama sehingga kegagalan dan resiko yang akan dihadapi akan semakin kecil dan dapat dikatakan cukup mahir dalam menjalankan usaha pengolahan gula aren. Jumlah tanggungan keluarga pengusaha gula aren ratarata 4 orang, menunjukkan bahwa Jumlah tanggungan keluarga rata-rata 4 orang merupakan tanggungan yang kecil sehingga pengusaha gula aren bisa membiayai usaha dengan baik.

\section{Luas Tempat Usaha}

Luas lahan tempat usaha pengusaha gula aren yang satu dengan Pengusaha gula aren yang lain. rata-rata luas lahan usaha pengolahan gula aren sampel adalah sebesar $28,71 \mathrm{~m}^{2}$, dimana luas lahan usaha yang terbesar terdapat pada Desa Ingin Jaya sebesar $29,90 \mathrm{~m}^{2}$ dan luas lahan yang terkecil terdapat pada Desa Jamur Labu yaitu sebesar $27,30 \mathrm{~m}^{2}$.

\section{Penggunaan Tenaga Kerja}

Penggunaan tenaga kerja pada usaha pengolahan gula aren meliputi kegiatan penyadapan aren, pengangkutan, pemasakan gula, pencetakan, pengemasan dan pemasaran. Dalam menghitung besarnya pencurahan tenaga kerja yang diserap untuk setiap fase kegiatan, seluruhnya dikonversikan ke dalam Hari Kerja Pria (HKP). Tenaga kerja yang digunakan pada usaha pengolahan gula aren terdiri dari tenaga kerka dalam keluarga (TKDK) dan tenaga kerja luar keluarga (TKLK). Rata-rata penggunaan tenaga kerja usaha pengolahan gula aren di Kecamatan Rantau dilihat pada tabel V-3 berikut. 
Tabel V-3. Rata-Rata Penggunaan Tenaga Kerja Usaha pengolahan gula aren di Kecamatan Rantau, 2017

\begin{tabular}{|c|l|c|c|r|}
\hline No & Nama Desa & $\begin{array}{c}\text { TKDK } \\
\text { (HKP/Tahun) }\end{array}$ & $\begin{array}{c}\text { TKLK } \\
\text { (HKP/Tahun) }\end{array}$ & $\begin{array}{c}\text { Total TK } \\
\text { (HKP/Tahun) }\end{array}$ \\
\hline 1 & Ingin Jaya & 44.72 & 1.80 & 46.52 \\
2 & Jamur Labu & 45.04 & 1.85 & 46.89 \\
3 & Durian & 50.56 & 1.91 & 52.47 \\
\hline \multicolumn{2}{|r|}{ Rata-rata } & 46.90 & 1.85 & 48.75 \\
\hline
\end{tabular}

Sumber : Data primer diolah, 2017

Tabel V-3 di atas dapat dilihat bahwa rata-rata pengunaan tenaga kerja usaha pengolahan gula aren di Kecamatan Rantau yaitu sebesar 48,75 HKP/Tahun. Rata-rata penggunaan tenaga kerja terbesar di Desa Durian sebesar 52,47 HKP/Tahun dan terkecil di Desa Ingin Jaya sebesar 46,52 HKP/Tahun.

\section{Biaya Produksi Usaha Pengolahan Gula Aren}

Rata-rata penggunaan biaya produksi perusaha sampel pada usaha pengolahan gula aren di Kecamatan Rantau dapat dilihat pada tabel V-4 berikut.

Tabel V-4. Rata-Rata Biaya Produksi Usaha Pengolahan Gula Aren di Kecamatan Rantau, 2017

\begin{tabular}{|c|c|c|c|c|}
\hline No & Nama Desa & $\begin{array}{l}\text { Biaya Tetap } \\
\text { (Rp/Tahun) }\end{array}$ & $\begin{array}{l}\text { Biaya Variabel } \\
\text { (Rp/Tahun) }\end{array}$ & $\begin{array}{l}\text { Total Biaya } \\
\text { (Rp/Tahun) }\end{array}$ \\
\hline 1 & Ingin Jaya & $711.395,00$ & $22.991 .990,00$ & $23.703 .385,00$ \\
\hline 2 & Jamur Labu & $676.815,00$ & $20.902 .670,00$ & $21.579 .485,00$ \\
\hline 3 & Durian & $707.215,15$ & $22.453 .581,82$ & $23.160 .796,97$ \\
\hline & Rata-rata & $698.756,99$ & $22.126 .967,74$ & $22.825 .724,73$ \\
\hline
\end{tabular}

Sumber : Data Primer, diolah 2017

Tabel V-4 di atas dapat dilihat rata-rata biaya produksi usaha pengolahan gula aren di Kecamatan Rantau yaitu sebesar Rp. 22.825.724,73/tahun. Rata-rata penggunaan biaya tetap sebesar Rp. 698.756,99/tahun dan biaya variabel sebesar Rp. 22.126.967,74/tahun. Biaya produksi terbesar terdapat pada Desa Ingin Jaya sebesar Rp. 23.703.385,00/tahun dan biaya produksi terkecil terdapat pada Desa Jamur Labu sebesar Rp. 21.579.485,00/tahun.

\section{Produksi Usaha Pengolahan Gula Aren}

Rata-rata produksi usaha pengolahan gula aren di Kecamatan Rantau dapat dilihat pada tabel V-5 berikut ini.

Tabel V-5. Rata-Rata Produksi Pada Usaha Pengolahan Gula Aren di Kecamatan Rantau, 2017

\begin{tabular}{|c|c|c|}
\hline No & Nama Desa & Produksi (Kg/Tahun) \\
\hline 1 & Ingin Jaya & $1.947,50$ \\
2 & Jamur Labu & $1.770,70$ \\
3 & Durian & $1.830,82$ \\
\hline \multicolumn{2}{|c|}{ Rata-rata } & $1.849,06$ \\
\hline
\end{tabular}

Sumber : Data Primer, diolah 2017

Tabel V-5 dapat dilihat bahwa rata-rata produksi usaha pengolahan gula aren di
Kecamatan Rantau yaitu sebesar $1.849,06$ $\mathrm{Kg} /$ tahun. Rata-rata produksi tertinggi berada 
di Desa Ingin Jaya yaitu sebesar 1.947,5 $\mathrm{Kg} /$ tahun dan terkecil berada di Desa Jamur Labu sebesar 1.770,7 Kg/tahun.

\section{Nilai Produksi (Pendapatan Kotor) Usaha Pengolahan Gula Aren}

Nilai produksi (pendapatan kotor) adalah total perkalian produksi dan harga produksi yang diterima pengusaha gula aren dari usahanya. Besarnya nilai produksi sangat ditentukan oleh harga yang berlaku saat pengusaha gula aren menjual hasil produksinya. Pada saat penelitian ini dilakukan harga gula aren di Kecamatan Rantau adalah Rp. 17.500 - Rp. 20.000 per kilogram. Rata-rata nilai produksi usaha pengolahan gula aren di Kecamatan Rantau dapat dilihat pada tabel V-6 berikut ini.

Tabel V-6. Rata-Rata Nilai Produksi Pada Usaha Pengolahan Gula Aren Kecamatan Rantau, 2017

\begin{tabular}{|c|l|c|}
\hline No & Nama Desa & Nilai Produksi (Rp/Tahun) \\
\hline 1 & Ingin Jaya & $37.026 .250,00$ \\
2 & Jamur Labu & $33.716 .500,00$ \\
3 & Durian & $34.514 .772,73$ \\
\hline \multicolumn{2}{|c|}{ Rata-rata } \\
\hline
\end{tabular}

Sumber : Data Primer, diolah 2017

Tabel V-6 di atas dapat dilihat bahwa rata-rata pendapatan kotor usaha pengolahan gula aren di Kecamatan Rantau yaitu sebesar Rp.35.067.419,35/tahun. Rata-rata nilai produksi tertinggi berada di Desa Ingin Jaya yaitu sebesar Rp.37.026.250/tahun dan terkecil berada di Desa Jamur Labu sebesar Rp.33.716.500/tahun.

\section{Pendapatan Bersih Usaha Pengolahan Gula Aren}

Pendapatan bersih sangat dipengaruhi oleh besarnya nilai produksi dan besarnya biaya produksi usaha pengolahan gula aren. Pendapatan bersih yaitu selisih antara nilai produksi dengan total biaya produksi. Ratarata pendapatan bersih usaha pengolahan gula aren di Kecamatan Rantau dapat dilihat pada tabel V-7 berikut ini.

Tabel V-7. Rata-Rata Pendapatan Bersih Usaha Pengolahan Gula Aren di Kecamatan Rantau, 2017

\begin{tabular}{|c|l|c|r|r|}
\hline No & Nama Desa & $\begin{array}{c}\text { Nilai Produksi } \\
\text { (Rp/Tahun) }\end{array}$ & $\begin{array}{c}\text { Biaya Produksi } \\
\text { (Rp/Tahun) }\end{array}$ & $\begin{array}{c}\text { Pendapatan Bersih } \\
\text { (Rp/Tahun) }\end{array}$ \\
\hline 1 & Ingin Jaya & $37.026 .250,00$ & $23.703 .385,00$ & $13.322 .865,00$ \\
2 & Jamur Labu & $33.716 .500,00$ & $21.579 .485,00$ & $12.137 .015,00$ \\
3 & Durian & $34.514 .772,73$ & $23.160 .796,97$ & $11.353 .975,76$ \\
\hline \multicolumn{2}{|r|}{ Rata-rata } & $35.067 .419,35$ & 22.825 .724 .73 & $12.241 .694,62$ \\
\hline
\end{tabular}

Sumber : Data Primer, diolah 2017

Tabel V-7 di atas dapat dilihat bahwa rata-rata pendapatan bersih usaha pengolahan gula aren di Kecamatan Rantau yaitu sebesar Rp.12.241.694,62/tahun. Rata-rata pendapatan bersih tertinggi berada di Desa Ingin Jaya yaitu sebesar Rp.13.322.865,00/tahun dan terkecil berada di Desa Durian sebesar Rp. 11.353.975,76/tahun.

\section{Analisis Kelayakan Usaha Pengolahan Gula Aren di Kecamatan Rantau}

Untuk menganalisis apa usaha pengolahan gula aren di Kecamatan Rantau layak atau tidak untuk dikerjakan maka dilakukan analisis finansial dengan 4 (empat) kriteria penilaian investasi yaitu: NPV, Net $\mathrm{B} / \mathrm{C}$, IRR dan PBP. Hasil analisis finansial usaha pengolahan gula aren di Kecamatan Rantau dapat dilihat pada tabel V-8 berikut. 
Tabel V.8. Hasil Analisis Kalayakan Finansial Usaha Pengolahan Gula Aren di Kecamatan Rantau, 2017

\begin{tabular}{|c|c|c|c|l|}
\hline No & Kriteria Investasi & Hasil Analisis & Kriteria Penerimaan & Kesimpulan \\
\hline 1 & NPV & Rp. 63.561.623,48 & $>0$ & Layak \\
2 & IRR & $26,13 \%$ & $>12 \%$ & Layak \\
3 & Net B/C & 9,02 & $>1$ & Layak \\
4 & PBP & 1,56 Tahun & $<5$ Tahun & Layak \\
\hline
\end{tabular}

Sumber : Data Primer, diolah 2017

Tabel V-8 menjelaskan bahwa hasil analisis kelayakan finansial untuk 4 (empat) penilaian kriteria investasi semuanya layak. Nilai NPV sebesar Rp. 63.561.623,48 adalah lebih besar dari 0 maka dari sisi NPV usaha pengolahan gula aren di Kecamatan Rantau layak untuk dikerjakan karena keuntungan bernilai positif. Nilai IRR sebesar 26,13\% lebih besar dari bunga pinjaman bank berlaku yaitu $12 \%$, maka dari sisi IRR usaha pengolahan gula aren di Kecamatan Rantau layak untuk dikerjakan karena jika harus mengembalikan pinjaman bank keuntungan masih di atas bunga pinjaman bank. Nilai Net $\mathrm{B} / \mathrm{C}$ sebesar 9,02 adalah lebih besar dari 1, maka dari sisi Net B/C usaha pengolahan gula aren di Kecamatan Rantau layak untuk dikerjakan karena nilai investasi akan memperoleh pengembalian sebesar 9,02 kali lipat atau misal investasi pada usaha pengolahan gula aren sbesar Rp. 1.000.000,akan memperoleh penerimaan bersih sebesar Rp. 9,020.000,- perperiode waktu yang diperhitungkan. Nilai PBP sebesar 1,56 tahun adalah lebih kecil dari umur proyek yaitu 5 tahun, maka dari sisi PBP usaha pengolahan gula aren di Kecamatan Rantau layak untuk dikerjakan karena investasi akan dapat dikembalikan waktu 1,56 tahun sehingga sisa umur proyek pengusaha dapat menikmati keuntungan.

\section{KESIMPULAN DAN SARAN Kesimpulan}

1. Karakteristik pengusaha sampel adalah umur rata-rata pengusaha gula aren sampel adalah 46,29 tahun, tingkat pendidikan rata-rata adalah 9,10 tahun, pengalaman berusaha gula aren 10,10 tahun dan jumlah tanggungan keluarga pengusaha gula aren rata-rata 4 orang

2. Rata-rata pengunaan tenaga kerja usaha pengolahan gula aren di Kecamatan Rantau yaitu sebesar 48,75 HKP/Tahun, rata-rata biaya produksi yaitu sebesar Rp. 22.825.724,73/tahun, rata-rata produksi gula aren yaitu sebesar 1.849,06 Kg/tahun, rata-rata nilai produksi yaitu sebesar Rp.35.067.419,35/tahun dan rata-rata pendapatan bersih yaitu sebesar Rp.12.241.694,62/tahun.

3. Hasil analisis kelayakan finansial untuk 4 (empat) penilaian kriteria investasi semuanya layak. Nilai NPV sebesar Rp. 63.561.623,48 (layak karena > 0), Nilai IRR sebesar 26,13\% (layak karena > bunga bank $12 \%$ ), Nilai Net B/C sebesar 9,02 (layak karena Net B/C > 1) dan Nilai PBP sebesar 1,56 tahun (layak karena PBP $<5$ tahun)

\section{Saran-saran}

1. Diharapkan kepada pengusaha gula aren di Kecamatan Rantau untuk dapat meningkatkan pendapatan usaha yang dikelolanya dengan cara menambah faktor produksi yang mempunyai pengaruh langsung terhadap produksi usaha pengolahan gula aren, sehingga pada akhirnya juga akan meningkatkan pendapatan dan kesejahteraan pengusaha

2. Pengusaha agar dapat memproduksi gula aren dengan berbagai varian produk agar mendapatkan harga produk yang lebih tinggi.

3. Perlu adanya penyuluhan secara kontinyu kepada para pengusaha gula aren tentang pentingnya menjalankan usaha pengolahan gula aren secara intensif sehingga diharapkan akan meningkatkan produksi yang optimal dan meningkatkan pendapatan pengusaha.

\section{DAFTAR PUSTAKA}

Adisasmita, Rahardjo, 2006, Pembangunan Pedesaan dan Perkotaan, Graha Ilmu Yogyakarta. 
Alwi, 2004. Pasar Modal: Teori dan Aplikasi Cetakan Pertama, Yayasan Pancur Siwah, Jakarta.

FAO [Food and Agriculture Organization]. 2014. Guar Gum. http://www.fao.org [7 Juli 2014].

Gittinger, J. Price dan Adler. A Hans. 1993. Analisis Ekonomi ProyekProyek Pertanian. Cetakan Ketiga. PT. Rineka Cipta. Jakarta.

Hadisapoetra. 2000. Biaya dan Pendapatan di Dalam Usahatani. UGM: Yogyakarta

Hernanto, F., 2004. Ilmu Usahatani. Penebar Swadaya, Jakarta.

Husein Umar, 2003. Metode Riset Bisnis, Jakarta: PT Gramedia Pustaka Utama

Husein Umar, 2007. Metode Studi Kelayakan Bisnis, Jakarta: PT Gramedia Pustaka Utama

Ibrahim, Yakob. 2010. Studi Kelayakan Bisnis. Bineka Cipta. Jakarta.

Kadariah, 2001. Evaluasi Proyek : Analisis Ekonomis. Lembaga Penerbitan Fakultas Ekonomi Universitas Indonesia. Jakarta

Ken Suratiyah, 2006. Ilmu Usahatani, Penebar Swadaya, Jakarta

Krisnamurthi, B. 2009. Langkah Sukses Menuju Agribisnis. Penebar Swadaya. Jakarta.

Mubyarto, 2002. Pengantar Ekonomi Pertanian. LP3ES. Jakarta.
Ngangi, 2001. Agroindustri Membangun Bangsa, Rineka Cipta, Jakarta.

Pasaribu, Amudi, 1981. Pengantar Statistik, Ghalia Indonesia, Jakarta.

Rahim, A., 2008. Sistem Manajemen Agribisnis. State University of Makasar Press

Riyanto, B. 2002. Dasar-Dasar Pembelanjaan Perusahaan. Yayasan Badan Penerbit Gadjah Mada, Yogyakarta.

Saladin, 2003. Marketing, Bumi Aksara, Jakarta

Soekartawi, 2002. Ilmu Usahatani dan Penelitian Untuk Pengembangan Petani Kecil, Penerbit Universitas Indonesia, Jakarta

Soeseno, Slamet. 2000. Bertanam Aren, Penebar Swadaya, Jakarta

Soetriono, A.S. 2006. Pengantar Ilmu Pertanian: Agraris, Agrobisnis dan Industri. Malang: Bayumedia.

Sudjana, 2003. Teknik Analisis Regresi dan Korelasi. Penerbit Tarsito. Bandung.

Sugiono, 2012. Metode Penelitian Kuantitatif dan $R \& D$, Alfabeta, Bandung

Suprapto, 2003. Karakteristik, Penerapan, dan Pengembangan Agroindustri Hasil Pertanian di Indonesia. Jakarta. Universitas Mercu Buana.

Tohar, 2004. Membuka Usaha Kecil. Kanisius. Yokyakarta 